Упровадження програми «НУШ у поступі до цінностей» також пов'язуємо із вихованням в учнів тих цінностей, які повною мірою охоплюють наскрізний процес виховання та простір життєдіяльності особистості, а також демонструють їх вихованість. Переконані, що духовно-моральна та змістово-технологічна значущість програми виховання на спільних цінностях у закладах освіти регіону дуже важлива. Навчаючись цінностям як особистісним та соціально значущим постулатам, смислам, нормам людського існування, учні проявлятимуть справедливу поведінку, дружні відносини, позитивні судження, доброчесні вчинки, активні дії.

Таким чином, моделюючи наскрізне виховання цінностей у Новій українській школі, здійснюємо пряме соціально-педагогічне замовлення на виховання свідомого духовно-багатого громадянина-патріота, що робить наповнення програми виховання на спільних цінностях та розробки закладів освіти щодо iii упровадження своєчасними та допоможе учням стати успішними людьми, повноцінними господарями власного життя задля забезпечення національного і духовного поступу нації й України.

\section{СПИСОК ВИКОРИСТАНОЇ ЛІТЕРАТУРИ}

1. Абетка для директора. Рекомендації до побудови внутрішньої системи забезпечення якості освіти у закладі загальної середньої освіти. - Київ, Державна служба якості освіти, 2019. - 240 с.
2. Гжегорчик А. Спроба змістового опису світу цінностей та їі етичні наслідки / А. Гжегорчик // Філософія освіти. - 2017. - № 2. - C. 115-152. URL: http:// nbuv.gov.ua/UJRN/PhilEdu_2017_2_9 (дата звернення: 21.03.2020).

3. Вишневський О. На шляху реформ. Актуальні питання сучасної української освіти та змісту виховання. Вибрані науково-публіцистичні праці / О. Вишневський. - Дрогобич : Коло, 2005. - 176 с.

4. Підкасистий П. І. Педагогіка : навч. посіб. для студ. пед. вузів і пед. коледжів. - М. : Педагогічне товариство Росії, 1998. - 640 с.

5. Програма «Нова українська школа» у поступі до цінностей. URL: https://ipv.org.ua/prohrama-novaukrainska-shkola/ (дата звернення: 24.03.2020).

6. Савченко О. Я. Виховний потенціал початкової освіти : [посіб. для вчителів і методистів почат. навч.] / О. Я. Савченко. - Вид. 2-ге, доп. і перероб. - К. : [Видав. Богданова А. М.], 2009. - 225 с.

7. Сухомлинська О. В. Духовно-моральне виховання дітей та молоді: загальні тенденції й індивідуальний пошук / О. В. Сухомлинська. - Київ, 2006. $43 \mathrm{c}$.

8. Ціннісні орієнтири сучасної української школи. - Київ : Міністерство освіти і науки України, 2019. -63 c.

Дата надходження до редакиї: 14.05.2020 p.

Ольга КІЯН, кандидат педагогічних наук, завідувач сектору експериментальної педагогіки відділу інновачійної діяльності та дослідно-експериментальної роботи

ДНУ «Інститут модернізаиї̈ змісту освіти», м. Київ

\title{
МОРАЛЬНО-ДУХОВНЕ ВИХОВАННЯ ОСОБИСТОСТІ МОЛОДШОГО ПІДЛІТКА
}

У статті окреслено тенденції діяльності закладу освіти, щео спрямовані на формування базових морально-духовних иінностей молодших підлітків. Одним із пріоритетних завдань, пов'язаних із вихованням молодого покоління, постає морально-духовне виховання зростаючої особистості, яка, соиіалізуючись у сучасних умовах, набувала б відповідних рис і морально-духовних иінностей, щяо характеризують ї̈ як громадянина.

Ключові слова: мораль, моральність, духовність, морально-духовне виховання, молодші підліт-

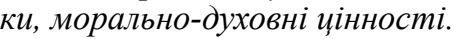

B cтатье обозначены тенденичи деятельности учебного заведения, направленные на формирование базовых морально-духовных иенностей младших подростков. Одной из приоритетных задач, связанных с воспитанием молодого поколения, стает нравственно-духовное воспитание растущей личности, которая, сочиализируясь в современных условиях, приобретала бы соответствующих черт и нравственно-духовных иенностей, что характеризуют ее как гражданина.

Ключевые слова: мораль, нравственность, духовность, нравственно-духовное воспитание, младиие подростки, нравственно-духовнье ценности.

The article reveals the trends of the educational institution in the formation of the basic moral and spiritual values of younger adolescents in the theory and practice of pedagogical science related to the upbringing of the younger generation, describes the age characteristics of young adolescents in the context of their moral and spiritual upbringing. 
It has been clarified that understanding of spirituality and morality has gone from a clear definition of concepts as a religious and cultural code to filling with philosophical and anthropocentric content.

The moral and spiritual upbringing of younger adolescents is a process that guides them to conscientious responsible behavior, due to their knowledge of moral and spiritual values, positive attitude towards them, ability to show moral qualities and make moral choices. This is due to the presence of a sufficiently large number of various factors that, depending on the genetic data of a particular personality, in one way or another affect the development of all its components: the spiritual-moral and psychosocial spheres, intelligence, creativity.

Recognizing that the decisive role in achieving the completeness and completeness of the moral and spiritual education of younger adolescents is played by objective factors - social, economic, legal, cultural, we believe that the school can now make a significant contribution to education in this direction.

Key words: moral, morality, spirituality, moral and spiritual upbringing, younger adolescents, moral and spiritual values.

Постановка проблеми. Сьогодні в контексті сучасного розвитку освіти України наше суспільство переживає важливий та досить складний час творення нової української школи.

На сучасному етапі країна потребує модернізації виховної системи освіти на принципах компетентнісного та діяльнісного підходів, зокрема формування морально-духовної особистості активного патріота, який знає і розуміє історію та культуру своєї Батьківщини, прагне до фізичної і моральної досконалості, готовий до самоосвіти, самовизначення та самореалізації в дорослому житті. Основою сучасної системи виховання є національна ідея, над якою працюють вихователі закладів дошкільної освіти, керівники гуртків і творчих об'єднань, методисти закладів позашкільної освіти, вчителі початкових класів, учителі-предметники, класні керівники, заступники директорів і директори закладів загальної середньої освіти.

Інноваційна парадигма виховання полягає в розумінні дитини як суб'єкта і мети виховання, орієнтує на усвідомлення виховання як соціально-педагогічного явища та на підвищення виховного потенціалу освітнього середовища й проєктування цілісного виховного простору. Пріоритетним напрямом у роботі 3 дітьми є приділення особливої уваги формуванню ідентичності основ духовності особистості, культури мислення та поведінки, профілактиці шкідливих звичок, а також ризикованої, девіантної і кримінальної поведінки, жорстокості і насилля в учнівському середовищі, різних видів залежностей.

Аналіз наукових досліджень та публікацій. Теоретичну основу дослідження складають: теорії та концепції самоцінності й моральної позиції особистості (Г. Ващенко, Г. Сковорода, А. Маслоу, К. Роджерс), наукові ідеї щодо закономірностей морально-духовного виховання особистості (I. Бех, К. Журба, Е. Помиткін), основні положення про сутність морально-духовного виховання особистості молодшого підлітка (О. Докукіна, Т. Кравченко, Л. Повалій, В. Постовий, І. Хоменко, О. Хромова, Н. Щуркова) тощо.

Сучасні науковці (I. Бех, М. Білова, К. Десятник, К. Журба, Д. Левчук, О. Сухомлинська та ін.) розглядають морально-духовне виховання особистості з погляду культурології, тобто вивищення в цьому процесі засобів науки, мистецтва, мови, народних традицій, звичаїв, етики.

Домінуючу роль релігійного компонента, що реалізується через духовну просвіту і сприйняття релігійних цінностей, у морально-духовному становленні обгрунтовують Р. Анісімова, О. Вишневський, М. Євтух, І. Климишин, Б. Нечипоров, Л. Повалій, В. Хайрулина, Л. Шугаєва та ін.

Мета статті - висвітлити досвід науково-експериментального обгрунтування сутності морально-духовного виховання особистості молодшого підлітка; окреслити стан розробленості проблеми в психолого-педагогічній теорії.

Зважаючи на мету статті, основними їі завданнями $є$ : аналіз діяльності закладу освіти, спрямованої на формування базових морально-духовних цінностей молодших підлітків, окреслених у теорії і практиці педагогічної науки та пов'язаних із вихованням молодого покоління; характеристика вікових особливостей дітей молодшого підліткового віку в контексті їх морально-духовного виховання.

Виклад основного матеріалу. У складних умовах розбудови української державності, національного відродження України, позначеного трансформацією світоглядних орієнтацій, серед значної кількості проблем, пов'язаних із вихованням молодого покоління, особливої значущості набуває проблема морально-духовного виховання зростаючої особистості, актуалізуючи таким чином проведення досліджень в означеному напрямі.

Для визначення сутності цього чинника необхідно розглянути його складові, до яких належать насамперед такі поняття, як «мораль», «моральність», «духовність», «морально-духовне виховання особистості».

Під поняттям «мораль» розуміється «сукупність історично зумовлених правил, норм, звичаїв, принципів співжиття і поведінки людей, їх відносини в процесі виробництва матеріальних і духовних цінностей, що визначають їх обов'язки один до одного, до соціальних груп, верств, класів, до суспільства, виконання яких грунтується на громадській думці» [5, с. 246].

Мораль виконує роль регулятора поведінки за допомогою гносеологічної, соціологічної, регулятивної, виробничої, ідеологічної (виховання) функцій тощо. Ще Я. Коменський, звертаючись до розгляду сутності морального виховання, писав: «Навчаючи моральності, слід ретельно розкривати перед юнаками істинну мету нашого життя, а саме, що ми народжені не тільки для себе, а й для Бога і для ближніх» [4, с. 12].

Мораль досить мінлива, відносна і різноманітна в різні епохи та в представників різних верств населення. Однак мораль абсолютна в тому сенсі, що на кожному етапі історичної еволюції мораль $є$ саме мораллю, а не чимось іншим.

Як відомо, поведінку особистості значною мірою зумовлюють соціально-психологічні явища. Виникаючи як продукт спілкування, вони поступово набувають відносної самостійності, здійснюючи регулюючий вплив на вчинки людей. Це зумовлено наявністю досить значної кількості різноманітних чинників, які, залежно від генетичних даних конкретної особистості, тією чи іншою мірою впливають на розвиток усіх iii складових: духовно-моральну і психосоціальну сфери, інтелект, креативність тощо. Підгрунтям цього процесу стає своєрідний механізм соціальної саморегуляції, який зазвичай характеризується певною випадковістю, непередбачуваністю. 
В іншому випадку зазначений вплив є певним чином детермінованим і таким, що надходить від професійно підготовлених фахівців - педагогів. Тут йдеться про механізм педагогічної регуляції духовно-морального стану і поведінки особистості, який можна розглядати як цілеспрямований вплив на іiі свідомість із метою формування певних стійких якостей. Саме свідомість людини $\epsilon$ вищим регулятором iіi поведінки і дій, адже будь-який імпульс до дії, виникаючи під впливом внутрішнього стану особистості або зовнішніх обставин, завжди співвідноситься 3 поглядами, ідеями, принципами і нормами, що склалися в людини, i, відповідно, санкціонуються або гальмуються ними [7, с. 150].

Існує також визначення моралі, згідно 3 яким вона розуміється як сукупність етичних уявлень про добро, справедливість, честь, відповідальність. Тут наголошується, що репрезентація етичних уявлень у свідомості індивіда забезпечує особистісну мораль, яка передбачає «орієнтацію людини на виконання системи соціальних норм відповідно до цінностей суспільства. А це означає підпорядкованість суспільних норм вагомішим цінностям» [7, с. 61].

Моральність - це буттєвий корелят моралі, що набуває вираження у звичаях і норові. Моральність виникла 3 життєвої практики людей і є однією з найважливіших сфер людських відносин. Останнім часом у теорії етики затвердився понятійний поділ моралі та моральності, де перше поняття виражає специфіку моральної свідомості або морально належне, а друге - реально існуючі моральні відносини людей або звичаї, в яких відступи від норм і принципів моралі постають як данина, суперечність самого буття. Звідси моральність тлумачиться як «характеристика особливого виду практичної діяльності людей, що мотивується моральними ідеалами, переконаннями, нормами і принципами» [6, с. 526].

На думку В. Киричок, правомірним $є$ розгляд моралі як «сфери моральної свободи особистості, коли суспільні та загальнолюдські вимоги збігаються 3 внутрішніми мотивами» [6, с. 527]. У цьому разі моральність постає як сфера «самодіяльності і творчості людини, внутрішнього примушування завдяки особистій свідомості, що переходить у схильність і спонтанне спонукання творити добро» [6, с. 527].

3 одного боку, моральний індивід $\epsilon$ суверенною особистістю, яка володіє волею і діє як причина i мета своїх вчинків, а з іншого - сфера моралі вищою мірою нормована, закладені в ній вимоги мають абсолютну владу. Мораль починається там, де добровільно враховуються не лише свої, а й чиїсь інтереси та бажання. «Вона починається 3 добровільного вчинку, «програшу» окремої приватної особи в ім'я єдності 3 іншими людьми, але цей вчинок має стати власним вибором індивіда, подоланням ним помилок, самоомани, самозадоволення» [14, с. 13].

Щодо моральності, то її варто розглядати як реальний стан моральної свідомості, стосунки, вчинки людей, тобто те, що є, на противагу тому, що мало б бути. За такого підходу моральність «є внутрішньою ціннісною основою духовності, культури суб'єкта, яка спрямовує людську активність на ствердження самоцінності особистості, усвідомлення обов'язків людини перед іншими людьми, перед Батьківщиною, суспільством, природою» [6, с. 527]. У ставленні до особистості моральність є метою, перспективою іiі вдосконалення та насамкінець вимогою.
Духовне життя людини - це життя в світі цінностей. Завдяки свідомості та самосвідомості людина реалізує духовне життя за власним вибором, але при цьому вона керується своєю совістю як внутрішнім регулятором людських вчинків; це закон, який живе в кожній людині, але формується суспільними відносинами. Отже, духовно розвинена людина - це така, яка має гідність, честь та обов'язки перед суспільством. Вона має право на різноманітні прояви своєї особистості, якщо вони не заважають життю інших людей та життєдіяльності суспільства загалом. Така людина глибоко усвідомлює саму себе, може свідомо керувати своїми вчинками, підпорядковуючи їх нормам моралі і вимогам людяності, вона співпереживає, співрадіє, співчуває.

Ян Коменський у своїй знаменній «Материнській школі», закликаючи найбільше доглядати за душею як найважливішою частиною людини, писав про те, що передусім необхідно привчати дітей до благочестя, потім - до доброти, моралі або чесноти і нарешті - «до найбільш корисних наук». Духовність є одночасно частиною людської сутності і соціальним феноменом, який являє собою складне комплексне утворення, що включає сукупність різноманітних форм свідомості від найвищих (світогляду, ідей, цінностей, ідеалів, переконань) до буттєвих (життєвих інтересів), ментальних особливостей та психоемоційних станів окремої людини чи народу, що обумовлює розуміння та ставлення людини чи багатьох людей до буття.

Наведені вище визначення й ознаки духовності $\epsilon$ відображенням певного аспекту цього поняття. Однак усі автори одностайні в тому, що духовність $є$ суто людською характеристикою, яка відрізняє людину від тваринного світу розвитком спрямованості й самосвідомості. Саме духовність дає людині можливість «усвідомити себе частиною єдиного цілого - людської спільноти, природи, Всесвіту. Втрата єдності - одна 3 найболісніших втрат у житті людини. Вона може відбуватися в різних площинах: від втрати єдності 3 близькою людиною - до втрати єдності з певною людською спільнотою, природою, Богом» [9, с. 29].

Феномен духовності постає у двох взаємопов'язаних сенсах - релігійному та світському його проявах. У релігійному розумінні духовність позначає глибинну сутність людини як родової істоти, духовне відродження духу в людині після іiі зустрічі з Богом, божественність. У такому тлумаченні виховання духовності передбачає опанування основ релігії, зокрема християнства й християнської моралі. У світському розумінні духовність - це зосередженість на моральній культурі людства, своєрідний інтелектуально-чуттєво-емоційний стан, психічна якість, здатність особистості до вдосконалення і самовдосконалення через засвоєння духовних цінностей культури. У цьому сенсі можливе понятійне концептуальне поєднання моралі й духовності у процесі виховання особистості, тобто використання поняття «морально-духовне виховання».

У межах соціології термін «виховання» розглядається як властивість індивіда, що характеризує його соціальні устремління.

Згідно з поглядами А. Маслоу основними рисами людини, що досягла високого рівня особистісного виховання, можна вважати такі, як:

- свободу вибору - вміння здійснювати життєвий вибір за власним бажанням;

- життєрадісність та енергійність у повсякденному житті; 
- досягнення значного успіху в діяльності, оскільки вона є для людини об'єктом самовираження;

- прагнення до самопізнання, вияву особистісних можливостей;

- цілісне сприйняття світу;

- внутрішню гармонію, багатий внутрішній світ.

У педагогічному сенсі під вихованням особистості розуміється така ії ознака, яка відображає устремління індивіда до участі в суспільному житті, його прийняття, а також сукупність особистісних ставлень, психологічних особливостей, певних якостей [9, с. 47].

Серед останніх у контексті нашого дослідження важлива роль відводиться морально-духовним їх різновидам. При цьому проблеми морально-духовного виховання особистості були висвітлені у працях вітчизняних та зарубіжних педагогів минулого та сучасності.

Ще К. Ушинський зазначав, що морально-духовне виховання дитини передбачає формування в неї гуманності, почуття національної і власної гідності в поєднанні зі скромністю, чесності й правдивості, патріотизму, працьовитості. Завдання і зміст педагогічної діяльності, яка має забезпечити належний рівень духовно-морального виховання зростаючої особистості він визначав з огляду на вселюдські, народні й національні культурні цінності, зважаючи на вимоги народних чеснот і норм християнської моралі, дбаючи, щоб така діяльність розвивала в дитини твердий характер і волю, стійкість, почуття громадянського обов'язку [13, с. 27-28].

Морально-духовне виховання особистості Г. Ващенко вважав неодмінною рисою виховного ідеалу, до складових якого він відносив служіння Богові і своїй нації, що забезпечується завдяки прояву таких якостей, як правдивість, працелюбність, людяність, щиросердність і гостинність, вірність у коханні, статева стриманість і здоровий сімейний побут, доброта, справедливість, милосердя. Зростаюча особистість, на переконання педагога, має бути правильною і чесною у своїх помислах та діях, усвідомлювати свою відповідальність перед Богом, власною совістю, попередніми, нинішніми та прийдешніми поколіннями [3, с. 109].

На думку О. Вишневського, самим життям доведено, що моральність не можна побудувати на грунті бездуховності. Із цього приводу він писав: «Занепад віри, як засвідчує історія, завжди супроводиться знеціненням у суспільстві морально-етичних вартостей. Проте все ж стрижнем моральності, в кожному разі стосовно суспільства загалом, завжди залишається духовність, моральний закон, записаний таємничою силою в серці кожної людини. Зародки моральності діють у душі дитини, навіть якщо у своєму моральному розвитку вона ще не дійшла до усвідомлення свого високого обов'язку» [4, с. 7].

У педагогіці напрям морально-духовного виховання розглядається як специфічна наукова і практична діяльність людей, спрямована на духовний розвиток, моральне самовдосконалення, самовиховання, засвоєння соціального досвіду.

Українці здавна поціновували такі риси, як працьовитість, повагу до старших і до жінок, чесність та порядність тощо. Але найбільше, як зазначає М. Стельмахович, вони піклувалися про «плекання духовності», моральне здоров'я і духовний розвиток дитини, тобто про формування «світоглядно-морально-етичного внутрішнього світу дитини» [11, с. 100], оскільки «розуміння дитиною сутності, норм і принципів моралі сприяє виробленню моральних думок і критеріїв оцінки своїх та чужих учинків; ...на основі моральних понять, оцінок, помислів і досвіду поведінки формуються моральні переконання, які зумовлюють вчинки особистісні» [11, с. 185].

Водночас учений зауважує, що духовну порожнечу, в якій опинився український народ, слід заповнювати не будь-яким духом, а лише добрим, тобто народним, святим. Тому й педагогічна сутність духовності полягає у вихованні дітей на засадах народної моралі, обізнаності з релігійною культурою, шанобливим ставленням до неї.

Емпіричним шляхом, стверджує М. Стельмахович, народна педагогіка дійшла висновку, що вдале просування морально-духовного розвитку дитини сприяє виробленню таких важливих рис, як почуття власної гідності, честі, совісті, радості чи смутку, тривоги й хвилювання не лише за себе, а й за інших людей, за сім'ю, родину, долю України, а також почуття краси, любові, віри [11, с. 186].

На думку науковців, для духовно-морального виховання особистості більш прийнятним є підхід, за якого відбувається поєднання релігійного і культурологічного аспектів, що обов'язково передбачає формування в неї моральних почуттів і моральної поведінки.

У цьому випадку методологічною основою духовно-морального виховання $\epsilon$ культура i релігія, представлені в різних аспектах:

- культурно-історичному (історія культури та історія України);

- морально-етичному (у контексті морального християнського вчення про людину, мету ії життя та ставлення до людей, Бога, світу);

- етнокультурному (національні народні традиції).

В означеному контексті під морально-духовним вихованням особистості розуміємо таку властивість, яка спонукає ії до турботливої і доброчинної поведінки, що грунтується на знаннях про моральні й духовні цінності, позитивному ставленні до них, уміннях проявляти моральні якості, робити моральний вибір.

Найбільш сенситивним періодом морально-духовного виховання особистості є молодший підлітковий вік. У цей час у дитини виникають і набувають розвитку потреби в пізнанні самої себе та інших людей, усвідомленні своїх якостей і потенційних можливостей.

Підлітковий вік характеризується більшою, порівняно 3 попереднім періодом, диференційованістю емоційних реакцій і способів вираження емоційних станів. Водночас дітям цього віку притаманна мінливість настрою - переходи від невпинних веселощів до суму, поєднання полярних якостей, прояви яких змінюють один одного, зумовлюючи суперечність поведінки. Так, чутливість до оцінки іншими їхньої зовнішності, здібностей, умінь почасти супроводжується надмірною самовпевненістю і критичністю стосовно оточуючих, емоційною ригідністю; болюча сором'язливість - нахабністю; бажання бути визнаним і поціновуваним - підкресленою незалежністю; боротьба 3 авторитетами - обожнюванням випадкових кумирів, а чуттєве фантазування - сухим мудруванням.

Під час оцінювання однолітків та інших людей молодші підлітки нерідко припускаються помилок через характерне для цього віку невміння цілісного сприйняття особистості. Тому, сприймаючи окремі риси, дії, вчинки іншої людини (негативні чи позитивні), вони можуть покладати, виникаючі внаслідок цього власні уявлення, в основу створення загального іiі «образу». Це відбувається через те, що для молодших підлітків більшу роль відіграє зовнішній бік учинку чи поведінки, а не їх мета і мотиви. 
Психіка дітей цього віку характеризується нестійкістю у ставленні до самих себе; характерна для значної кількості підлітків недостатність розвитку вольової сфери, виявляється у відсутності достатньої наполегливості в подоланні наявних недоліків, особливо за умов відсутності зовнішньої підтримки. Їхній досвід активної моральної взаємодії з однолітками поки що недостатній, його треба розширювати і поглиблювати.

Період із 10 до 12 років $є$ тим віковим відрізком, коли учень уже не дитина, але ще й не повноцінний підліток, що, безумовно, породжує низку проблем. За словами I. Беха, «саме на межі дитинства й отроцтва у передпідлітковому віці (10-12 років) школярам необхідно допомогти в тій складній справі, якою вони напівсвідомо починають займатися: висунення завдань саморозвитку і пошук засобів їх вирішення» [1, с. 123].

Самооцінка підлітків часто буває завищеною i нестійкою, тоді як оцінювання інших відзначається більшою стриманістю, вдумливістю, конкретністю і глибиною.

Саме в молодшому підлітковому віці у дітей з'являється інтерес до свого внутрішнього світу, виникає бажання краще пізнати самих себе і сформувати адекватну самооцінку. Водночас вони відчувають, що не вміють, не можуть оцінити себе, не знають, яким чином і за допомогою яких критеріїв це можна зробити. Захисні особистісні механізми поведінки, які найбільш активно формуються в старшому підлітковому віці, ще не склалися: діти відкриті до спілкування 3 дорослими, їхня навіюваність підвищена, тому дорослі справляють на них значний вплив.

Суперечливість внутрішньої позиції молодшого підлітка полягає ще й у тому, що «з одного боку, він прагне до самостійності, протестує проти дріб'язкової опіки, контролю, недовіри», а з іншого - відчуває тривогу й побоювання, що не впорається з тим завданням, яке йому доручили, або яке він зголосився виконати, щоб довести свою самостійність і незалежність. Він «чекає від дорослого допомоги і підтримки, але не хоче відкрито визнати це». Тобто підліток не заперечує права дорослих втручатися в його життя, він «тільки шукає прийнятне для нього співвідношення піклування дорослих і власної незалежності» [1, с. 123].

Ця особливість потребує обов'язкового врахування при реалізації виховних дій, спрямованих на забезпечення морально-духовного виховання молодших підлітків. Тому не можемо не погодитися зі словами I. Беха, який стверджує, що «дорослий мусить бути товаришем підлітка, але товаришем особливим, відмінним від товариша-однолітка. Ця відмінність грунтується на відмінності соціальних позицій дорослого і молодої людини. «Дорослий товариш поруч» - це гасло має бути найважливішою умовою виховання i розвитку підлітка» [1, с. 122].

Основним показником психічного розвитку підлітка $є$ рівень його свідомості й самосвідомості. Свідомість забезпечує можливість подумки побудувати, спланувати, уявити майбутні дії та їх результати, тобто свідомість «забезпечує здатність розуміти свої дії, відповідати за них, «реєструвати» їх у своїй свідомості і висловлювати це розуміння словами». Самосвідомість знаходить відображення в оцінках своїх дій, ставленні до них [1, с. 126].

Таким чином, пріоритетного значення в розбудові сучасної нової школи набуває завдання формування в учнів системи загальнолюдських цінностей - морально-етичних (гідність, чесність, справедливість, турбота, повага до життя, повага до себе та інших) i соціально-політичних (свобода, демократія, культурне різноманіття, повага до рідної мови і культури, патріотизм, шанобливе ставлення до довкілля, повага до закону, солідарність, відповідальність). У центрі освіти має перебувати виховання в учнів відповідальності за себе та добробут нашої країни.

Висновок. Отже, проаналізувавши психологічні особливості молодших підлітків, можемо стверджувати, що віковий період від 10 до 12 років із властивою йому емоційністю, прагненням до самоствердження, почуттям дорослості, формуванням ціннісних орієнтацій, пошуками сенсу життя, активною самотворчою діяльністю і бажанням удосконалитися $\epsilon$ найбільш сенситивним для проведення виховної роботи, спрямованої на забезпечення морально-духовного виховання дитини цього віку. Адже духовність (за Н. Косарєвою) - такий рівень розвитку особистості й суспільства, що $є$ консолідуючим началом, здатним об'єднати людей на основі взаємної поваги і любові; це та сила, яка покликана стимулювати національне відродження України, забезпечити громадянський мир і злагоду в суспільстві.

Сучасна виховна система потребує комплексного підходу щодо їх розв'язання та розвитку соціально-педагогічної парадигми виховання на основі цінностей. Основою нової парадигми, а отже, й основою виховання є особистість дитини, визнання іiї найвищою цінністю, орієнтація педагога на гуманні, демократичні принципи спільної $з$ дитиною життєдіяльності.

Оскільки процес становлення України як суверенної, правової, демократичної держави, зорієнтованої на інтеграцію в європейське співтовариство, вимагає від освітньої галузі пошуку шляхів виховання успішної особистості, якій властиві морально-духовні цінності, готовність утверджувати їх своїми вчинками, справами та конкретною діяльністю, можемо констатувати, що нині ми переживаємо справжній ренесанс у педагогіці виховання: вона сповна одухотворюється.

\section{СПИСОК ВИКОРИСТАНОЇ ЛІТЕРАТУРИ}

1. Бех І. Д. Особистість у просторі духовного розвитку / І. Д. Бех. - Київ : Академвидав, 2012. - 246 с. (Серія «Альма-матер»).

2. Білоконь I. Духовна культура як чинник моральної і громадянської спрямованості / І. Білоконь // Соціальна психологія. - 2008. - № 6. - С. 59-66.

3. Ващенко Г. Виховний ідеал / Г. Ващенко. Полтава : Полтавський вісник, 1994. - 208 с.

4. Вишневський О. І. Теоретичні основи сучасної української педагогіки / О. І. Вишневський. - Дрогобич : КОЛО. $-2003 .-528$ с.

5. Енциклопедія освіти / Акад. пед. наук України ; відповід. ред. В. Г. Кремень. - К. : Юрінком Інтер, 2008. - 1040 с.

6. Киричок В. А. Проблема формування гуманістичних цінностей молодших школярів / В. А. Киричок // Теоретико-методичні проблеми виховання дітей та учнівської молоді : зб. наук. пр. / Ін-т проблем виховання АПН України. - К. = Житомир, 2004. - Кн. I. C. 193-200.

7. Коваль Л. Г. Соціальна педагогіка / Л. Г. Коваль, І. Д. Звєрєва, С. С. Хлебнік. - К. : ІЗМН, 1997. - 109 с.

8. Коменский Я. А. Материнская школа / Я. А. Коменский ; [препринт ; пер. с нем. М. Н. Воскресенской]. СПб. : Типография училища глухонемых, 1982. - 64 с. 
9. Помиткін Е. О. Психологія духовного розвитку особистості : [монографія] / Е. О. Помиткін. - К. : Наш час, 2005. - 280 c.

10. Практична педагогіка виховання : посіб. 3 теорії та методики виховання / за заг. ред. М. Ю. Красовицького, упор. Г. І. Іванюк. - К. = Івано-Франківськ : Плай, 2000. - 143 с.

11. Стельмахович М. Г. Українська народна педагогіка : навч.-метод. посіб. / М. Г. Стельмахович. -К. : I3MH, 1997. - $232 \mathrm{c}$.

12. Тимощук Н. С. Особистісно орієнтоване виховання старшокласників у процесі позакласної ро- боти : навч.-метод. посіб. / Н. С. Тимощук. - Рівне : Волинські обереги, 2004. - 281 с.

13. Ушинський К. Д. Людина як предмет виховання: спроба педагогічної антропології / К. Д. Ушинський // Твори : в 6 т. - К. : Рад школа, 1952. - Т. 4. $528 \mathrm{c}$.

14. Шмигіна Н. Соціальне середовище та формування особистості учня / Н. Шмигіна // Студент-2 : зб. наук. пр. ; за ред. М. Ф. Бойка. - Херсон : Айлант, 1999. $-68 \mathrm{c}$.

Дата надходження до редакиї: 18.02 .2020 р.
УДК 37.01

DOI: 10.37026/2520-6427-2020-102-2-150-153
Світлана КИРИЛЕНКО,

кандидат педагогічних наук, начальник відділу інноваџійної діяльності та дослідно-експериментальної роботи ДНУ «Інститут модернізації змісту освіти», м. Київ

\section{УЧИТЕЛЬ ЯК НОСІЙ ЦІННОСТЕЙ ВИХОВАННЯ В СУЧАСНОМУ ЗАКЛАДІ ЗАГАЛЬНОЇ СЕРЕДНЬОЇ ОСВІТИ}

У статті визначено мету професійної діяльності вчителя як вихователя $i$ носія иінностей $y$ сучасних закладах загальної середньої освіти, його прагнення до самовдосконалення, вивчення кращого педагогічного досвіду, інновачій в освіті, комунікачіі зі своїми колегами, активна громадянська позиція, патріотизм. Розглянуто умови для всебічного гармонійного розвитку особистості учня, його самореалізачії, розкриття індивідуальності, творчого потениіалу. Закиентовано увагу на превентивних заходах у роботі з дітьми, щзо визначаються приділенням особливої уваги формуванню ідентичності, основ духовності особистості, культури мислення $і$ культури поведінки, профілактиці шкідливих звичок, ризикованої девіантної поведінки, жорстокості $і$ насилля $в$ учнівському середовищі.

Ключові слова: сучасний учитель, парадигма виховання, різновекторність виховних впливів, морально-етичні иінності, гармонійний розвиток особистості учня, творчий потенціал педагога.

В статье определень иели профессиональной деятельности учителя как воспитателя и носителя ценностей в современных учреждениях общего среднего образования, его стремление к самосовершенствованию, изучение лучшего педагогического опьыта, инноваций в образовании, ком- муникации со своими коллегами, активная гражданская позиция, патриотизм. Рассмотрено условия для всестороннего гармоничного развития личности ученика, его самореализаџии, раскрытия индивидуальности, творческого потенциала. Обрамено внимание на превентивные меры в работе с детьми, что определяются уделением особого внимания формированию идентичности, основ духовности личности, культуры мылиления и культуры поведения, профилактике вредных привычек, рискованного девиантного поведения, жестокости и насилия в ученической среде.

Ключевые слова: современный учитель, парадигма воспитания, разновекторность воспитательных воздействий, морально-этические иенности, гармоничное развитие личности ученика, творческий потенцииал педагога.

The purpose of professional activity of teacher as educator and carrier of values in modern institutions of general secondary education is defined in the article; striving for self-improvement, teaching of advanced pedagogical experience, communication with colleagues, active civic position, patriotism; the conditions for comprehensive harmonious development of the student's personality, his / her self-realization, revealing of individuality, creative potential are revealed. Attention is paid 